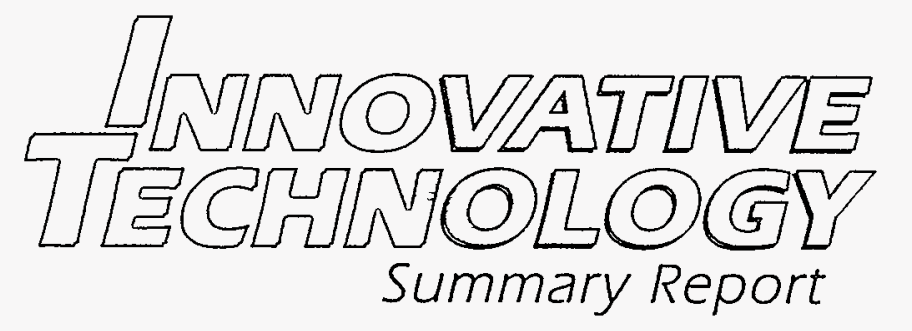

DOE/EM-0430

\title{
Corrosion Probe
}

Tanks Focus Area

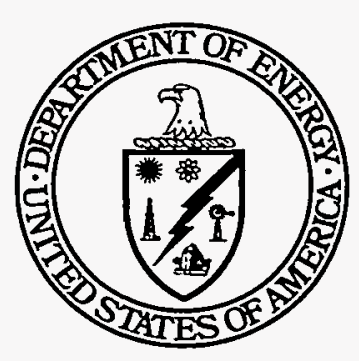

Prepared for U.S. Department of Energy Office of Environmental Management Office of Science and Technology

May 1999 


\section{Corrosion Probe}

OST Reference \#1985

\section{Tanks Focus Area}

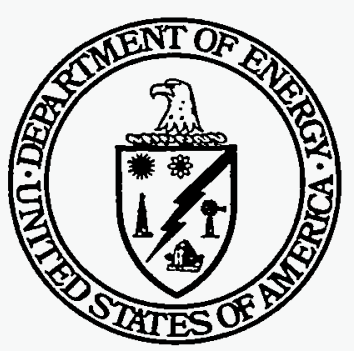

Demonstrated at Hanford Site

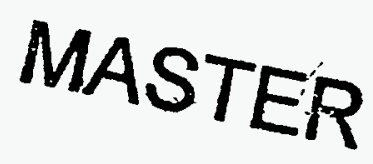

Richland, Washington 


\section{DISCLAIMER}

Portions of this document may be illegible in electronic image products. Images are produced from the best available original document. 


\section{DISCLAIMER}

This report was prepared as an account of work sponsored by an agency of the United States Government. Neither the United States Government nor any agency thereof, nor any of their employees, make any warranty, express or implied, or assumes any legal liability or responsibility for the accuracy, completeness, or usefulness of any information, apparatus, product, or process disclosed, or represents that its use would not infringe privately owned rights. Reference herein to any specific commercial product, process, or service by trade name, trademark, manufacturer, or otherwise does not necessarily constitute or imply its endorsement, recommendation, or favoring by the United States Government or any agency thereof. The views and opinions of authors expressed herein do not necessarily state or reflect those of the United States Government or any agency thereof. 
Summary Report

\section{Purpose of this document}

Innovative Technology Summary Reports are designed to provide potential users with the information they need to quickly determine if a technology would apply to a particular environmental management problem. They are also designed for readers who may recommend that a technology be considered by prospective users.

Each report describes a technology, system, or process that has been developed and tested with funding from DOE's Office of Science and Technology (OST). A report presents the full range of problems that a technology, system, or process will address and its advantages to the DOE cleanup in terms of system performance, cost, and cleanup effectiveness. Most reports include comparisons to baseline technologies as well as other competing technologies. Information about commercial availability and technology readiness for implementation is also included. Innovative Technology Summary Reports are intended to provide summary information. References for more detailed information are provided in an appendix.

Efforts have been made to provide key data describing the performance, cost, and regulatory acceptance of the technology. If this information was not available at the time of publication, the omission is noted.

All published Innovative Technology Summary Reports are available on the OST Web site at http://OST.em.doe.gov under "Publications." 
2 TECHNOLOGY DESCRIPTION page 3

3 PERFORMANCE $\quad$ page 6

4 TECHNOLOGY APPLICABILITY AND ALTERNATIVES page 9

$5 \operatorname{cosT}$ page 10

6 REGULATORYIPOLICY ISSUES page 12

7 LESSONS LEARNED page 13

\section{APPENDICES}

\section{A References}

B List of Acronymns 


\section{SECTION 1}

\section{SUMMARY}

\section{Technology Summary}

Over 253 million liters of high-level waste (HLW) generated from plutonium production is stored in mild steel tanks at the Department of Energy (DOE) Hanford Site. Corrosion monitoring of double-shell storage tanks (DSTs) is currently performed at Hanford using a combination of process knowledge and tank waste sampling and analysis. Recent analyses showed that several DSTs were operating outside of chemistry specifications for corrosion control, indicating the current system of chemistry sampling is inadequate. In-tank, real-time, continuous measurement of waste corrosivity is needed to provide an acceptable level of corrosion control.

Available technologies for corrosion monitoring have progressed to a point where it is feasible to monitor and control corrosion by on-line monitoring of the corrosion process and direct addition of corrosion inhibitors. The electrochemical noise (EN) technique deploys EN-based corrosion monitoring probes into storage tanks (see Figure 1). This system is specifically designed to measure corrosion rates and detect changes in waste chemistry that trigger the onset of pitting and cracking. These on-line probes can determine whether additional corrosion inhibitor is required and, if so, provide information on an effective end point to the corrosion inhibitor addition procedure.

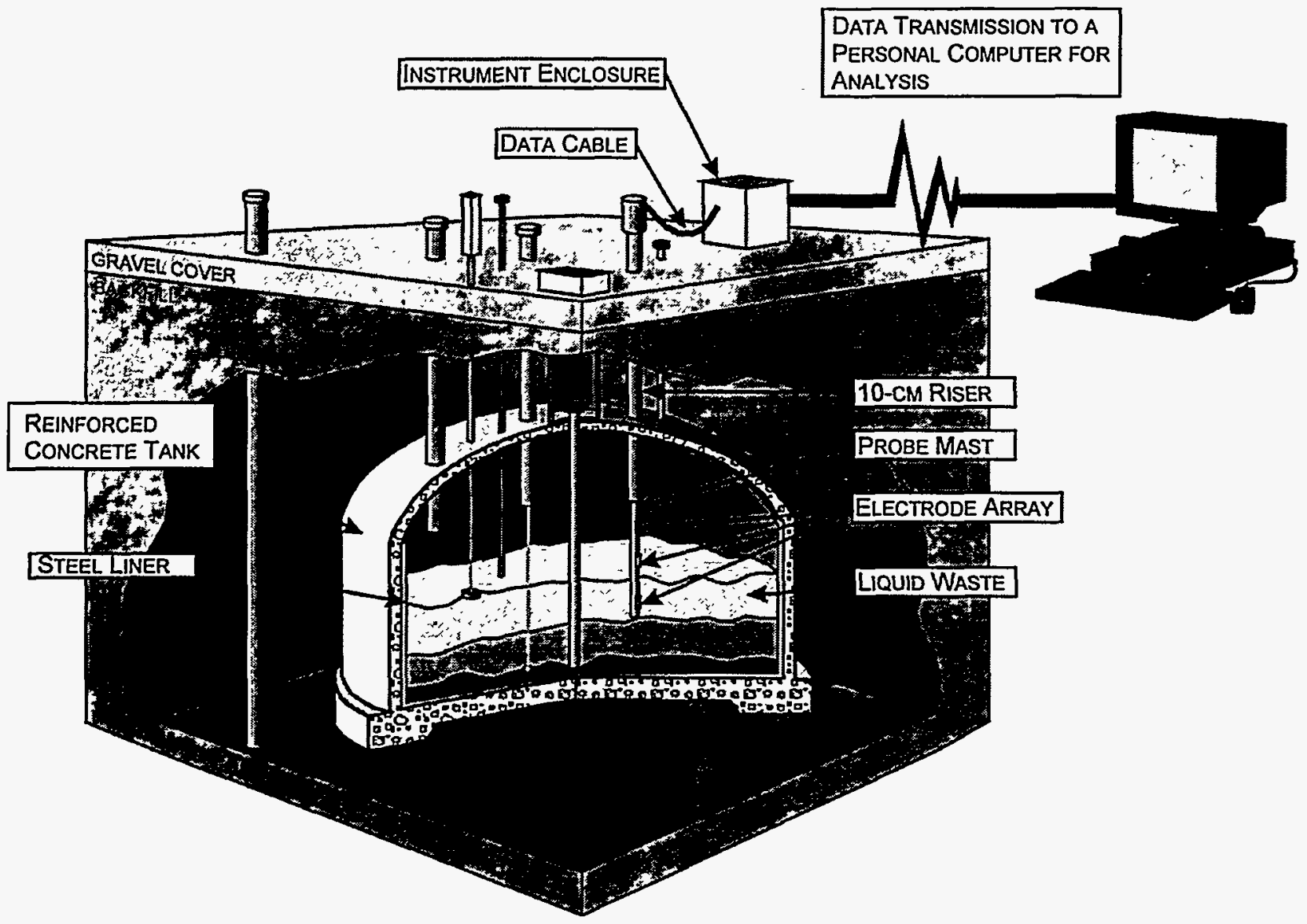

Figure 1. Schematic of Hanford Site prototype corrosion monitoring system.

Primary market applicability for corrosion probe monitoring is 28 DSTs located at Hanford. Savannah River Site (SRS) has 25 DSTs that could benefit from this technology. Other potential users may exist across the DOE complex. 
With the exception of process knowledge and tank waste chemistry sampling, no baseline corrosion monitoring system currently exists. The use of an EN system in HLW tanks will allow real-time monitoring of both corrosion processes and corrosion inhibitor addition. Real-time corrosion monitoring is more accurate than the system currently in use (predicting corrosion behavior based on waste chemistry specifications). The unnecessary addition of thousands of gallons of inhibitor, and the costs associated with the storage, treatment, and disposal of this additional waste can be avoided.

\section{Demonstration Summary}

EN-based corrosion probe efforts involve both laboratory trials at SRS and field-testing at the Hanford Site. Laboratory work and field application led to more refined demands for future systems.

Demonstrations and deployments included

- Prototype EN corrosion deployed in Hanford DST 241-AZ-101 on August 1, 1996

- First-generation operational probe deployed in Hanford DST 241-AN-107 in September 1997

- Second-generation EN-based corrosion monitoring probe installed in Hanford DST 241-AN-102 on September 1,1998

SRS is currently evaluating corrosion monitoring technology for deployment in SRS HLW tanks. Hanford is also planning additional deployments.

\section{Contacts}

Technical

Glenn L. Edgemon, Lockheed Martin Hanford Corp., Richland, WA, (509) 373-7214, E-mail:

glenn__edgemon@rl.gov

James L. Nelson, Lockheed Martin Hanford Corp., Richland, WA, (509) 373-6296, E-mail:

james_Ijim_nelson@ri.gov

\section{Management}

Ted Pietrok, Tanks Focus Area Management Team Lead, DOE-RL, Richland, WA, (509) 372-4546,

E-mail: theodore_p_pietrok@rl.gov

Kurt Gerdes, Tanks Focus Area Program Manager, EM-53, DOE, Germantown, MD, (301) 903-7289,

E-mail: kurt.gerdes@em.doe.gov

Mike Terry, TFA Safety Technical Integration Manager, Los Alamos National Laboratory, Richland, WA, (509) 372-4303, E-mail: mtt@lanl.gov

\section{Other}

All published Innovative Technology Summary Reports are available at $h$ ttp://em-50.doe.gov. The Technology Management System, also available through the EM-50 Web site, provides information about OST programs, technologies, and problems. The OST Reference Number for Corrosion Probe is \#1985. 


\section{Overall Process Definition}

Any gross corrosion process is the sum of many stochastic microelectrochemical corrosion events. These events can be measured as random fluctuations in corrosion current and corrosion potential between electrodes. These fluctuations are known as EN.

For many years, EN has been observed during corrosion (Eden, Rothwell, and Dawson 1991). Typically, EN consists of low frequency $(<1 \mathrm{~Hz})$ and small-amplitude signals that are spontaneously generated by electrochemical reactions occurring on corroding surfaces (Farrell 1991). Laboratory studies and recent reports have reported that EN analysis is well suited for monitoring and identifying the onset of localized corrosion and for measuring uniform corrosion rates (Hladky and Dawson 1982).

A typical EN-based corrosion monitoring system uses three nominally identical electrodes (working, counter, and pseudoreference) immersed in the environment of interest. EN is measured as time-dependent fluctuations in corrosion current between the working and counter electrodes. EN potential is measured as the time-dependent fluctuation of the difference in the corrosion potential between the working/counter electrode assembly and the pseudoreference electrode. A zero-resistance ammeter (ZRA) electrically joins the working and counter electrodes. The ZRA measures the potential differences between the workingl counter electrode assembly and the pseudoreference electrode (Doherty et al. 1996).

The prototype probe (see Figure 2) uses a combination of commercially available equipment and sitespecific tank intrusive equipment. The probe has three electrode arrays distributed along the length of the probe body. The two upper electrode arrays are positioned to monitor vapor-phase corrosion, while the lowermost array is immersed approximately $55 \mathrm{~cm}$ into the liquid waste.

To represent the actual tank walls, each electrode array consists of three C-ring (American Society for Testing and Materials (ASTM) G-38) electrodes constructed of archived ASTM A537-Class I tank steel. The working (center) electrode in the liquidphase array is precracked by cyclic fatigue and strained beyond the proportional limit just prior to immersion in the waste. The other two liquid-phase electrodes are not prestrained. The working electrodes of the vapor-space arrays are not precracked but are strained beyond the proportional limit prior to installation. Figure 3 shows the electrodes on an array of the prototype corrosion probe. Within each subarray of three electrodes, corrosion current is measured between electrodes 1 and 2 , and corrosion potential is measured between electrodes 2 and 3. A stressed, precracked $C$-ring is used as electrode 2 to generate the stresses required to detect the onset of stress corrosion cracking (SCC) (Edgemon et al. 1996).

Figure 4 shows an electrode array on the first generation probe. A similar array is used on the second generation probe.

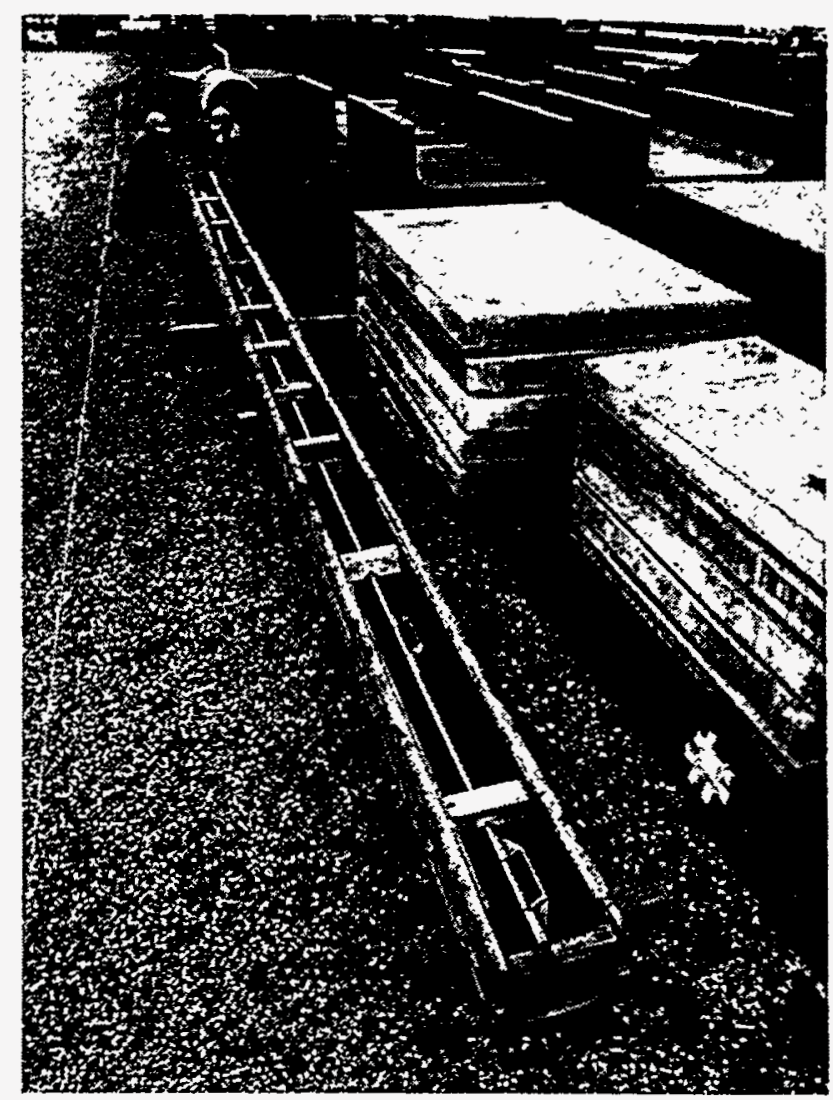

Figure 2. Prototype probe prior to installation in DST 241-AZ-101 (Source: Edgemon et al. 1996) 


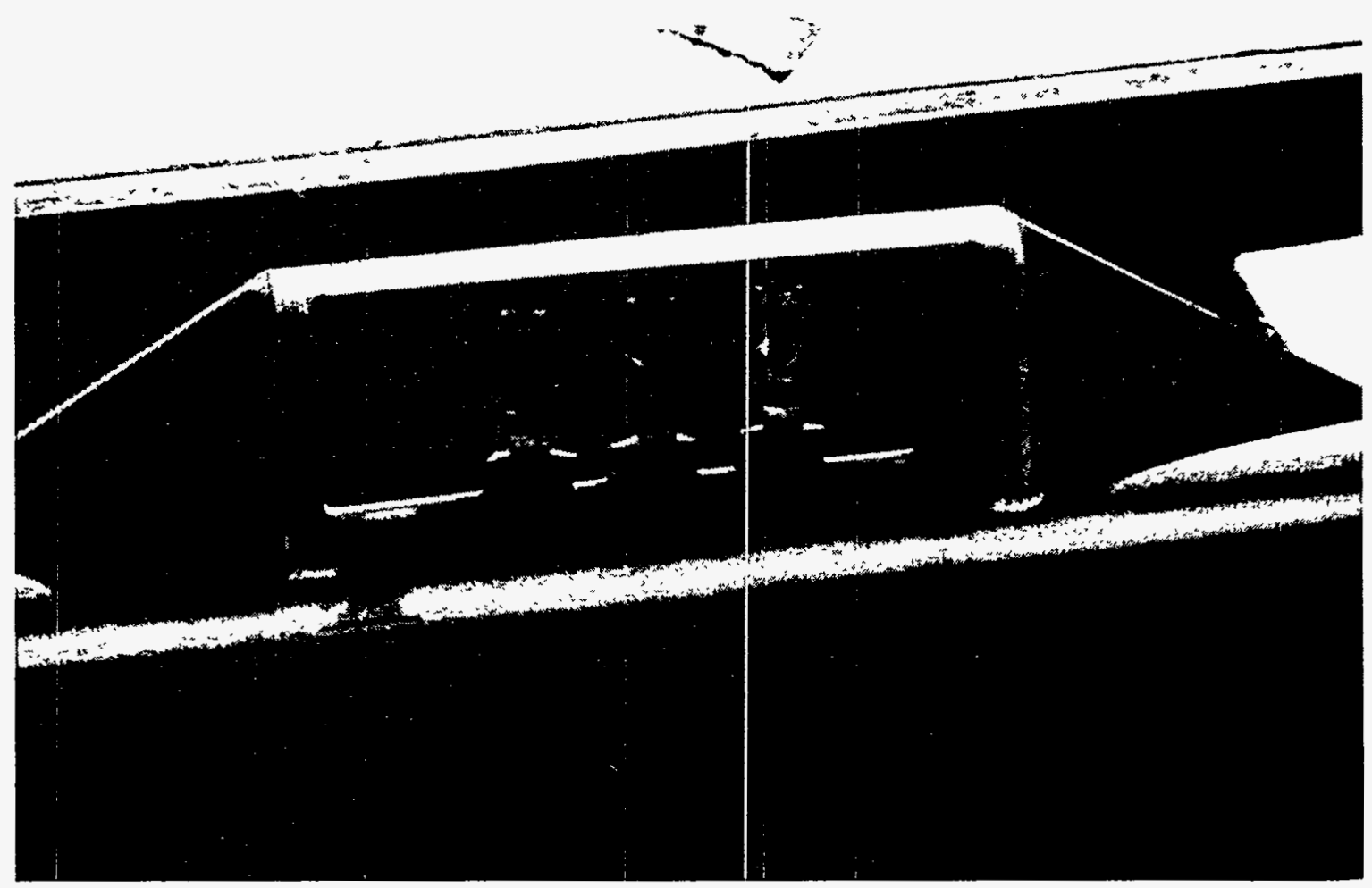

Figure 3. C-ring electrode array on prototype probe. The working (center) electrode is precracked by cyclic fatigue then strained beyond the proportional limit (near yield) prior to installation. (Source:

Edgemon et al. 1996)

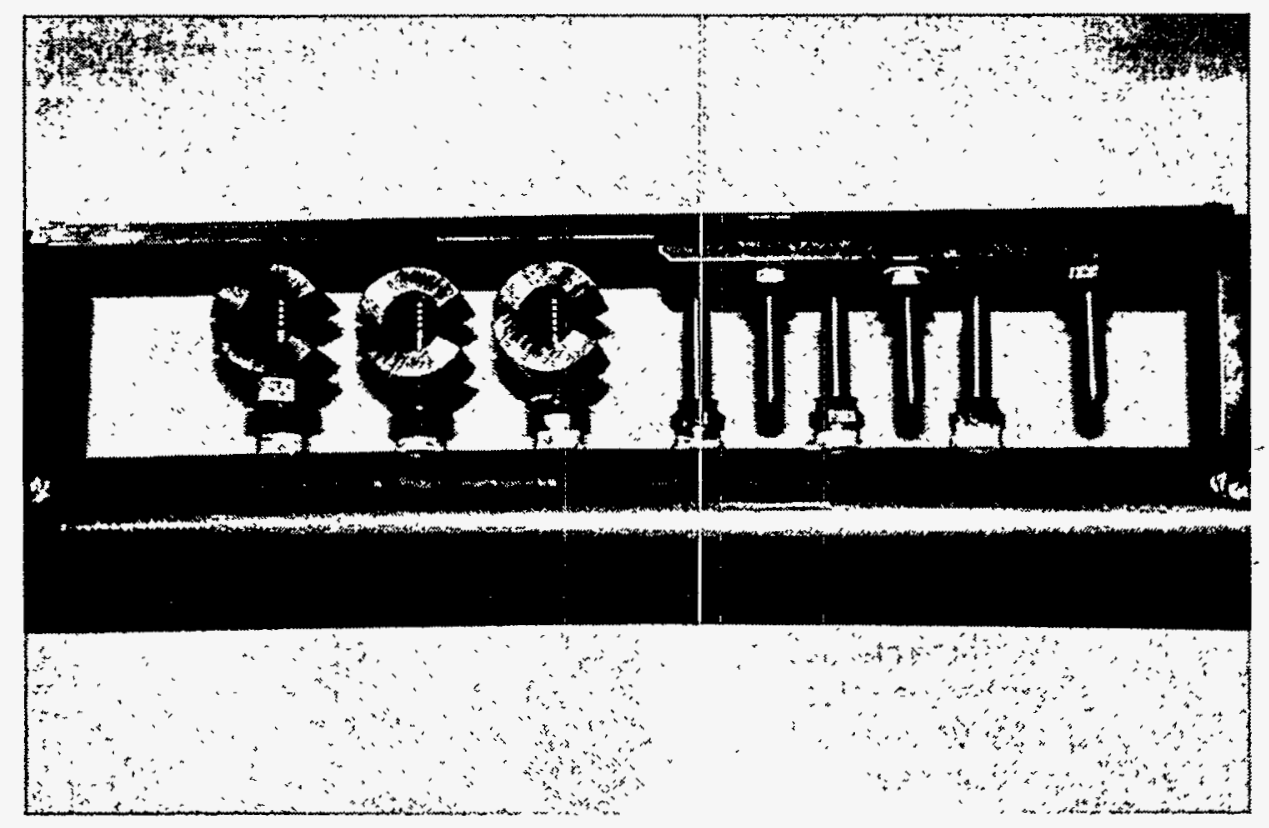

Figure 4. One of four subarrays on the first-generation probe. Each detector contains electrodes for two channels plus three long-term corrosion pins for weight loss data. (Source: Nelson 1998).

\section{Demonstration Goals and Objectives}

Table 1 describes equipment demonstrated from 1995-1998. The Tanks Focus Area will continue to develop improvements to the corrosion probe. 
Table 1. Equipment description and performance objectives

\begin{tabular}{|l|c|c|l|}
\hline \multicolumn{1}{|c|}{ Technology } & Tank & Date & \multicolumn{1}{|c|}{ Equipment Description } \\
\hline $\begin{array}{l}\text { Prototype corrosion } \\
\text { monitoring system }\end{array}$ & $241-\mathrm{AZ}-101$ & 1996 & $\begin{array}{l}\text { The probe is approximately 10-m long. Components } \\
\text { consist of an electrode array, underground cabling to a } \\
\text { nearby corrosion monitoring instrument, and a network } \\
\text { connection to a data acquisition and control console. } \\
\text { Each array consists of three subarrays of three } \\
\text { electrodes each (nine total). }\end{array}$ \\
\hline $\begin{array}{l}\text { First-generation } \\
\text { corrosion monitoring } \\
\text { system }\end{array}$ & $241-\mathrm{AN}-107$ & 1997 & $\begin{array}{l}\text { This probe is approximately 16.2-m long. The probe } \\
\text { has four two-channel electrode arrays (24 electrodes } \\
\text { total). Each channel uses three electrodes (Figure 4). } \\
\text { Advancements include glass-lined feed-trhoughs; a 25- } \\
\text { conductor, fully shielded data cable; a weather-resistant } \\
\text { enclosure; and an eight-channel data collection } \\
\text { system. }\end{array}$ \\
\hline $\begin{array}{l}\text { Second-generation } \\
\text { corrosion monitoring } \\
\text { system }\end{array}$ & $241-\mathrm{AN}-102$ & 1997 & $\begin{array}{l}\text { The chief improvements include improved extemal-tank } \\
\text { data collection electronics. }\end{array}$ \\
\hline
\end{tabular}

\section{System Operation}

Table 2 summarizes the system operation requirements for the EN-based corrosion probe.

\begin{tabular}{|c|c|}
\hline & Operational data \\
\hline Special operational parameters & $\begin{array}{l}\text { The system is deployed through a tank riser with a minimum } \\
\text { diameter of } 10 \mathrm{~cm} \text {. As with other technologies being deployed } \\
\text { in HLW tanks, several safety, environmental, and technical } \\
\text { considerations must be addressed prior to deployment. }\end{array}$ \\
\hline $\begin{array}{l}\text { Materials, energy, other expendable } \\
\text { items }\end{array}$ & $\begin{array}{l}\text { The corrosion data collection system consists of a data logger } \\
\text { for each probe, process control software, and a commerically } \\
\text { available data acquisition system. } \\
\text { Corrosion monitoring instrumentation relies on commercially } \\
\text { available electrochemical measurement systems and software. } \\
\text { Existing galvanic corrosion monitoring software was modified for } \\
\text { EN data collection. } \\
\text { Potential and current measurements are recorded once per } \\
\text { second on each active array. }\end{array}$ \\
\hline Personnel requirements & $\begin{array}{l}\text { Personnel operating the instrumentation must be trained in the } \\
\text { proper use of the hardware. } \\
\text { All of the data is collected from the corrosion probes via a } \\
\text { dedicated computer. A trained analyst is necessary to interpret } \\
\text { the results. } \\
\text { Personnel performing maintenance and installation/removal } \\
\text { must be properly trained. }\end{array}$ \\
\hline Secondary waste streams & $\begin{array}{l}\text { No secondary waste streams are generated during installation } \\
\text { or operation. Decontamination wastes may be generated on } \\
\text { system removal. }\end{array}$ \\
\hline $\begin{array}{l}\text { Special operational concerns and } \\
\text { risks }\end{array}$ & $\begin{array}{l}\text { For operational implementation of the probe throughout Hanford } \\
\text { and other DOE sites, more efficient data analysis (i.e., } \\
\text { interpretation without a trained analyst) is necessary. }\end{array}$ \\
\hline
\end{tabular}




\section{SECTION 3}

\section{PERFORMANCE}

\section{Demonstration Plan}

Table 3 describes the activities undertaken by each stage of corrosion probe development. The development of the corrosion probe monitoring technology at Hanford can be broken down into four major stages:

- Literature review

- Proof of principle and preliminary scoping studies

- Prototype deployment

- Full-scale deployment

Table 3. Development of corrosion probe monitoring technology

\begin{tabular}{|l|l|l|}
\hline Year & \multicolumn{1}{|c|}{ Stage } & \multicolumn{1}{|c|}{ Objectives } \\
\hline $\begin{array}{l}1994- \\
1996\end{array}$ & Literature review & Select a candidate corrosion probe technology \\
\hline $1996-$ & Preliminary Studies & Optimize corrosion probe design parameters \\
\hline 1997 & $\begin{array}{l}\text { Prototype deployment in 241- } \\
\text { AZ-101 }\end{array}$ & $\begin{array}{l}\text { Detect changes in the corrosive characteristics of waste and } \\
\text { correlate the characteristics with operational changes in the } \\
\text { tank. }\end{array}$ \\
\hline 1997 & $\begin{array}{l}\text { Full-scale deployment in 241- } \\
\text { AN-107 }\end{array}$ & $\begin{array}{l}\text { Deploy the first-generation system } \\
\text { Monitor eight channels: six positioned at different elecations in } \\
\text { the supernatant, and two positioned in the vapor space above } \\
\text { the waste. } \\
\text { Detect the onset of pitting and corrosion cracking should tank } \\
\text { waste conditions change to allow these mechanisms to occur. }\end{array}$ \\
\hline 1998 & $\begin{array}{l}\text { Second-generation } \\
\text { deployment in 241-AN-102 }\end{array}$ & $\begin{array}{l}\text { Detect the onset of localized corrosion phemomena should tank } \\
\text { conditions change to a state allowing these phenomena to occur } \\
\text { as a result of waste transfers. }\end{array}$ \\
\hline
\end{tabular}

\section{System Performance}

Table 4 summarizes the major elements and results of the demonstrations.

Proof-of-principle experiments yielded data showing that an EN probe could detect and discriminate between uniform corrosion, SCC, and pitting in mild steel/nitrate systems. Uniform corrosion is characterized by random fluctuations in current and potential raw data caused by random shifts between the anodically and cathodically dominated behavior of the electrodes. In mild steel/nitrate systems using a stressed working electrode, intergranular SCC crack advance is characterized by formation of a positively directed burst of current occurring simultaneously with a negatively directed burst in raw data potential. Pit initiation is characterized by the formation of numerous, short-lived, potential spikes indicative of momentary negative charge occurring simultaneously with numerous, short-lived current spikes. 
Table 4. Results of corrosion probe monitoring technology testing phase

\begin{tabular}{|l|l|}
\hline \multicolumn{1}{|c|}{ Developmental Stage } & \multicolumn{1}{|c|}{ Key Results } \\
\hline Literature review & $\begin{array}{l}\text { EN was selected as the candidate technology for localized corrosion } \\
\text { monitoring in HLW tanks. }\end{array}$ \\
\hline Proof of principle & $\begin{array}{l}\text { Uniform corrosion was observed in all } 40 \text { tests } \\
\text { Pitting was observed in } 26 \text { of the tests } \\
\text { SCC was observed in 9 of the tests (18 additional tests failed to produce } \\
\text { SCC in test specimens). } \\
\text { Statistical analysis of the raw data files can be used to identify time } \\
\text { periods of change in corrosion behavior. }\end{array}$ \\
\hline $\begin{array}{l}\text { Prototype deployment in 241- } \\
\text { AZ-101 }\end{array}$ & $\begin{array}{l}\text { Data indicative of pit initiation and growth was obtained following large } \\
\text { water additions to the tank. } \\
\text { Uniform corrosion is the dominant acitve corrosion mechanism in 241- } \\
\text { AZ-101 } \\
\text { Uniform corrosion rates remained under 1.0 mil per year (over the } \\
\text { operating time of the probe). }\end{array}$ \\
\hline $\begin{array}{l}\text { Full-scale deployment in 241- } \\
\text { AN-107 }\end{array}$ & $\begin{array}{l}\text { Uniform corrosion rates calculated from noise data collected on small } \\
\text { pin-type electrodes do not agree with uniform corrosion rates determined } \\
\text { from noise data collected on larger C-ring electrodes. }\end{array}$ \\
\hline $\begin{array}{l}\text { Second-generation } \\
\text { deployment in 241-AN-102 }\end{array}$ & $\begin{array}{l}\text { Results of the data analysis and recommendations regarding hardware } \\
\text { or software modification with be finalized in FY99 following a period of } \\
\text { operation. }\end{array}$ \\
\hline
\end{tabular}

Figure 5 shows actual data from the prototype corrosion monitor installed in tank 241-AZ-101. After November 1997, spikes and fluctuations in the data indicate that water additions $(>7,000$ gal) have induced pit initiation and growth in the electrodes. Pitting transients were recorded following five separate water additions of 7,000-26,000 gal. Because this particular tank is well inhibited, pitting corrosion decreased with time as the tank re-equilibrated.
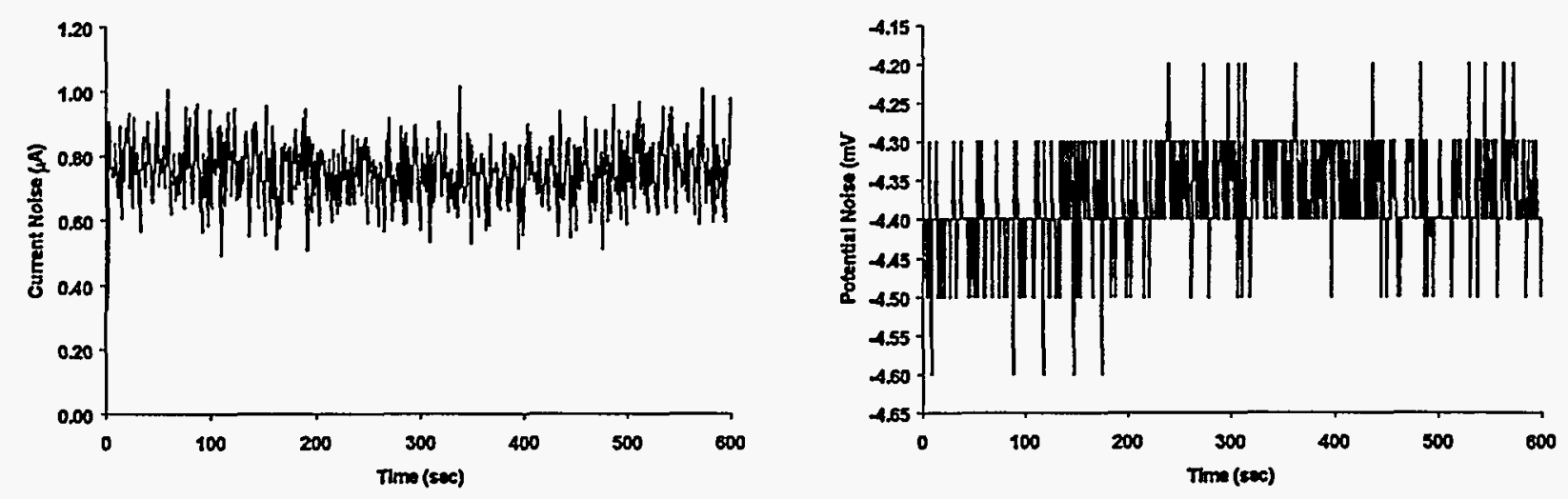

Current and potential data collected prior to November 1997 water addition (26,565 gal)

Figure 5. Typical data from DST 241-AZ-101. (Source: Nelson 1998). 

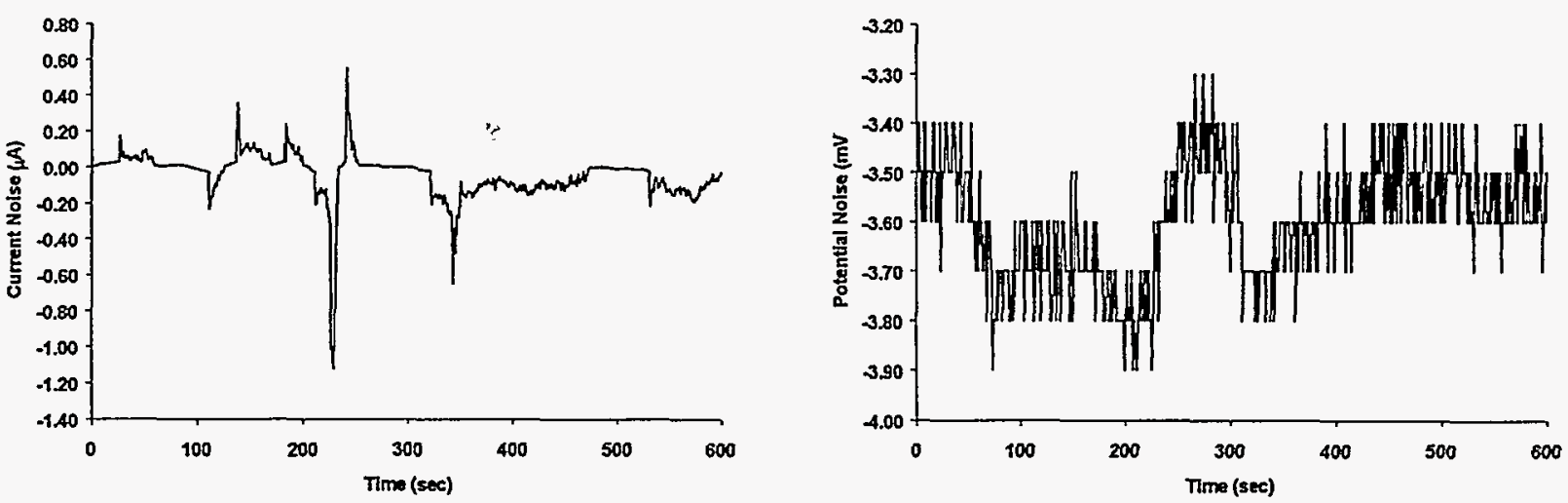

Current and potential data collected after November 1997 water addition $(26,565$ gal)

Figure 5 (continued). Typical data from DST 241-AZ-101. (Source: Nelson 1998).

The first-generation probe deployment in 241-AN-107 provided data used to calculate a uniform corrosion rate, capable of detecting the onset of SCC and pitting. An unknown interference is suspected of corrupting data; however, the source of disruption is external and not related to tank corrosion. This problem is being investigated.

The second-generation corrosion probe allows the user to configure alarm points to notify the user of dangerous corrosion conditions in the tank. The 241-AN-102 system software can be configured to allow cumulative storage of all data or to automatically discard data not recorded at a set interval of time on either side of an alarm event. This procedure minimizes the amount of EN data the user must evaluate. The firstgeneration system stores all data until manually sorted by the operator. 


\section{TECHNOLOGY APPLICABILITY \\ AND ALTERNATIVES}

\section{Competing Technologies}

In the past, baseline corrosion monitoring was addressed through waste chemistry interpretation and adjustment. The current technique for correcting this condition involves adding sodium hydroxide until a specified hydroxide concentration is achieved. Previous efforts to monitor internal corrosion in HLW tank systems have included linear polarization resistance (LPR) and electrical resistance techniques. These techniques are effective for monitoring uniform corrosion but are not well suited for detection of localized corrosion (pitting and SCC).

EN-based corrosion monitoring technology offers a number of benefits over the baseline:

- Increased safety due to the reduced risk of tank liner failure.

- Direct corrosion monitoring (rather than monitoring chemical species) will increase the accuracy of assumptions about tank waste homogeneity. Additionally, the inaccuracy associated with current corrosion chemistry-specification models will be reduced or removed.

- Real-time corrosion monitoring is more accurate than the current system of predicting corrosion behavior based on waste chemistry specifications.

- EN-based systems facilitate immediate identification of off-normal corrosive conditions. If they occur, mitigation efforts could be started in a more timely manner.

- Avoidance of unnecessary chemical additions due to unknown corrosion conditions-more than 10,000 gal of increased waste volume in tanks at Hanford through fiscal year 1996 resulted from sodium hydroxide additions. Direct monitoring of the actual tank corrosion conditions might have shown these additions to be unnecessary.

- Corrosion type and rate information collected by real-time monitoring would help determine the amount of design life lost due to abnormal corrosion conditions.

EN-based corrosion monitoring technology also offers significant potential for cost reduction:

- Real-time corrosion monitoring during inhibitor addition would eliminate costs associated with unnecessary inhibitor addition.

- Tank sampling and analysis are difficult and expensive. Waste streams exempt from the corrosion control specification complicate process knowledge.

- Sodium additions for corrosion control cost an estimated \$1 million per metric ton to vitrify.

- Extension of tank life and avoidance of premature replacement are possible due to more rapid identification of off-normal corrosion conditions. The cost associated with DST replacement as estimated by the Multi-Function Waste Tank Facility Project was $\$ 67$ million per tank.

\section{Technology Applicability}

EN-based corrosion monitoring technology is relatively new but has gained rapid acceptance in other private chemical processing industries. Future technical selection considerations would involve decisions regarding DSTs available at other facilities across the DOE complex.

\section{Patents/Commercialization/Sponsors}

This work was sponsored by DOE's EM-50, with cofunding by EM-30. For information on the commercialization of this technology, see the contact section. 


\section{Introduction}

A life-cycle cost evaluation was conducted to compare the use of baseline corrosion monitoring methods to the use of corrosion probes. Assumptions used to estimate savings are summarized in Tables 5 and 6 .

Table 5. Assumptions-Baseline corrosion control

\begin{tabular}{|l|l|}
\hline Supernate chemistry sampling & $\begin{array}{l}28 \text { tanks average 2-year sample frequency }=14 \text { samples annually } \\
\text { (assume 4 samples are shared with characterization and safety } \\
\text { programs) } \\
\text { Total annual corrosion monitoring samples required }=10 \\
\text { Each sample event allocated } \$ 62 \mathrm{~K}=\$ 620 \mathrm{~K} / \mathrm{year} \\
\$ 620 \mathrm{~K} \times 30 \text { years }=\$ 18,600 \mathrm{~K}\end{array}$ \\
\hline Additional specification work & $\begin{array}{l}\text { New process chemistry regimes requiring additional laboratory } \\
\text { coupon testing and specification development } \\
\text { Assume } \$ 300 \mathrm{~K} \text { over } 30 \text {-year life of analysis }\end{array}$ \\
\hline Corrective action & $\begin{array}{l}\text { Five tanks known to be operating outside existing chemistry } \\
\text { specification } \\
\text { Assume five additional tanks drift outside chemistry specifications } \\
\text { over remaining } 30 \text { years of this comparison } \\
\text { Corrective actions average } \$ 30 \mathrm{~K} \text { each } \$ 30 \mathrm{~K} \times 10 \text { corrective actions } \\
=\$ 300 \mathrm{~K}\end{array}$ \\
\hline Engineering labor & $\begin{array}{l}\text { One dedicated full-time equivalent (FTE) to monitor corrosion } \\
\text { processes and corrective actions for DSTs and transfer systems } \\
\$ 125 \mathrm{~K} \times 30 \text { years }=\$ 3,750 \mathrm{~K}\end{array}$ \\
\hline
\end{tabular}

Table 6. Assumptions-New corrosion monitoring probe technology

\begin{tabular}{|l|l|}
\hline Probe installation & $\begin{array}{l}\text { Install } 25 \text { additional corrosion probes } \\
\$ 60 \mathrm{~K} \times 25=\$ 1,500 \mathrm{~K}\end{array}$ \\
\hline Corrective action & $\begin{array}{l}\text { Corrective action for off-normal condition first requires chemistry } \\
\text { sample, then appropriate chemistry correction. If corrective actions } \\
\text { were reduced by a factor of } 2, \text { five tanks would require correction. } \\
5 \text { tanks } \times(\$ 62 \mathrm{~K} / \text { sample }+\$ 30 \mathrm{~K} / \text { correction) }=\$ 460 \mathrm{~K}\end{array}$ \\
\hline Disposal processing & $\begin{array}{l}\text { New process chemistry regimes requiring additional laboratory } \\
\text { coupon testing and specification development } \\
\text { Assume } \$ 300 \mathrm{~K} \text { over } 30-y e a r \text { life of analysis }\end{array}$ \\
\hline Engineering labor & $\begin{array}{l}\text { One dedicated FTE to monitor corrosion processes and corrective } \\
\text { actions for DSTs and transfer system } \\
\$ 125 \mathrm{~K} \times 30 \text { years }=\$ 3,750 \mathrm{~K}\end{array}$ \\
\hline
\end{tabular}




\section{Cost Analysis}

Table 7 compares estimated 30-year limited life-cycle costs for the existing baseline corrosion control method and installation of corrosion probes in the remaining 25 DSTs at Hanford (Nelson 1998). Estimated operational cost savings are $\$ 17$ million. This value does not include additional cost avoidance to be realized through waste volume reduction and subsequent vitrification minimization.

Table 7. Baseline corrosion control vs corrosion probe installation, in millions of dollars

\begin{tabular}{|l|r|l|r|}
\hline \multicolumn{2}{|c|}{ Baseline corrosion control } & \multicolumn{2}{c|}{ Corrosion probe installation } \\
\hline Supernatant samples & 18.6 & Install corrosion probes & 1.5 \\
\hline Additional speciation work & 0.3 & Additional speciation work & 0.3 \\
\hline Corrective action & 0.3 & Corrective action & 0.46 \\
\hline Engineering labor & 3.75 & Engineering labor & 3.75 \\
\hline Total & $\mathbf{2 2 . 9 5}$ & Total & \\
\hline
\end{tabular}

\section{Other Cost Savings Considerations}

In September 1997, the Tanks Focus Area conducted a cost savings analysis for corrosion probe and corrosion inhibitor monitoring that included cost savings to be achieved through waste volume reductions and vitrification minimization. The conclusions of the report were as follows:

- The time required to implement corrosion probe monitoring at Hanford is three years, and technology is expected to remain in operation for 30 -year life cycle.

- The unit cost savings from operating corrosion probes for 30 years equals approximately $\$ 2.3$ million per probe.

- At $\$ 2.3$ million per probe, total savings from using corrosion probes for 25 tanks at SRS and 25 DSTs at Hanford is estimated to be $\$ 58$ million per site.

Considering overall technology applicability and market value, the cost savings for both Hanford and SRS over 30-year life cycle could be over $\$ 100$ million. 


\section{REGULATORY AND POLICY ISSUES}

\section{Regulatory Considerations}

There are no known stakeholder or regulatory issues impacting deployment of this technology. The Comprehensive Environmental Response, Compensation, and Liability Act evaluation criteria do not apply to the intended application of this technology. However, Washington Administrative Code 173-303-640-(2)(c)(iii) for the underground storage of dangerous wastes requires an assessment of existing corrosion protection, but does not prescribe corrosion monitoring. Corrosion monitoring is not a part of the baseline DST System Integrity Assessment Program at Hanford. Radiological and industrial safety issues involved in the deployment of this technology are minimal and have been addressed as part of the installation of the probes into 241-AN-101 and 241-AN-107.

Real-time corrosion monitoring will provide an acceptable performance measurement of current corrosion protection measures and early warning of potentially corrosive conditions. The following are site-specific regulatory/permitting requirements:

- DOE Order 5820.2A, Radioactive Waste Management, requires monitoring of cathodic protection systems, methods for periodically assessing waste storage system integrity, and adjustment of waste chemistry to control corrosion. Real-time corrosion monitoring would assist in the integrity assessment of the DSTs.

- DOE-STD-1073-93, Configuration Management, requires implementation of a Material Condition and Aging Management Program to control aging processes in major equipment and components. The primary aging processes in waste tank systems are corrosion related.

- DOE/RL-92-60, Tank Waste Remediation System Functions and Requirements, contains corrosion control requirements for the waste storage (F-2.1.1) and waste transfer (F4.2.4.4) functions.

\section{Safety, Risks, Benefits, and Community Reaction}

Environmental safety and health compliance are addressed in the following documents:

- WHC-SD-WM-OSR-005, Single-Shell Tank Interim Operational Safety Requirements, WHC-SDWM-OSR-004, Aging Waste Facility Interim Operational Safety Requirements, and WHC-SDWM-OSR-016, Double-Shell Tank Interim Operational Safety Requirements, are support documents that contain interim operational safety requirements/administrative controls for corrosion control, cathodic protection, and integrity assessments. Implementation of these administrative controls necessitates corrosion monitoring and control activities.

- WHC-SD-PLN-068, TWRS Life Management Program Plan, identifies SCC, pitting corrosion, and uniform corrosion as the primary aging mechanisms for DSTs. Real-time corrosion monitoring of DSTs for these mechanisms will provide data necessary to develop damage prediction models for the DST Life Management Program.

- BNL/DOE-HQ Tank Structural integrity Panel, Guidelines for Development of Structural Integrity Programs for DOE High-Level Waste Storage Tanks-DRAFT discusses the important role of corrosion monitoring in the conduct of a comprehensive structural integrity program. 


\section{SECTION 7}

\section{LESSONS LEARNED}

The lengthy and careful development of EN-based corrosion monitoring systems at Hanford has resulted in a technologically sound and appropriate application. The existence of nearly 300 reports on laboratory tests and field applications of EN gives some indication as to the promise that this technique holds. The correlation of pitting EN with large water additions to tank 241-AZ-101 offers additional evidence of the usefulness of the application. Similarly, the potential use of EN to avoid the huge expense associated with unnecessary hydroxide additions to tank 241-AN-107 clearly demonstrates the need for further deployment of this technology.

\section{Implementation Considerations}

Laboratory trials and field applications show that EN is uniquely suited for the task of monitoring localized and general corrosion problems associated with the storage of HLW at Hanford and other DOE waste storage facilities. Other techniques, including LPR and electrical resistance are not well suited for detecting and discriminating between forms of localized corrosion.

The design requirements shown for both the prototype system in 241-AZ-101 and the systems in 241-AN107 and $241-A N-102$ have resulted in probes that were safely installed and that have returned useful data for over $25,000 \mathrm{~h}$ to date. Changes in the electronics package to facilitate more advanced data analysis should not affect the hardiness of the in-tank portion of the system. The design requirements meet structural demands and radiological demands for DSTs, with or without mixer pumps.

In addition to the qualifications listed above, the necessary electronic equipment can be installed in a weatherproof housing if no environment-controlled building is available near the installation site. The equipment can be operated remotely over the Hanford LAN or by modem to minimize as-low-as-reasonablyachievable concerns.

\section{Technology Limitations and Need for Future Development}

- The accuracy of the first- and second-generation systems should be evaluated against ASTMstandard LPR tests.

- Determine why the corrosion rates reported are dependent on electrode size.

- Improve the gasket seats in the system.

- The probe failure modes must be investigated. If data quality is affected by crevice corrosion under gasket surfaces, the design must be modified.

- SCC data needs to be obtained for more realistic tank waste simulants.

- New steel and archived steel must be compared in order to identify potential defects and initiationpoint effects. 


\section{APPENDIX A}

\section{REFERENCES}

Beaunier, L., J. Frydman, C. Gabrielli, F. Huet, and M. Keddam. 1996. In Proceedings of the first international symposium on electrochemical noise measurements for corrosion application, ed. J. R. Kearns, J. R. Scully, P. R. Roberge, D. L. Reichert, and J. L. Dawson. Philadelphia, PA: American Society for Testing and Materials, ASTM STP 1277, p. 114.

Department of Energy. 1997. Corrosion probe and corrosion inhibitor monitoring. Technical Task Plan RL08-WT-21.

Doherty, M. J. Psaila-Dombrowski, S. L. Harper, and W. G. Schneider. 1996. In Proceedings of the first international symposium on electrochemical noise measurements for corrosion application, ed. J. R. Kearns, J. R. Scully, P. R. Roberge, D. L. Reichert, and J. L. Dawson. Philadelphia, PA: American Society for Testing and Materials, ASTM STP 1277, p. 288.

Eden, A. N. Rothwell, and J. L. Dawson. 1991. "Electrochemical noise for detection of susceptibility to stress corrosion cracking," paper no. 444 in proceedings of CORROSION/91. Houston, TX: NACE International.

Edgemon, G. L., and G. E. C. Bell. 1996. Technical basis for electrochemical noise based corrosion monitoring of underground nuclear waste storage tanks. Westinghouse Hanford Company Report WHC-SD-WM-TI-772.

Edgemon, G. L., and J. L. Nelson. 1998. Design of second-generation Hanford tank corrosion monitoring system. Rev. 0. HNF-2517.

Edgemon, G. L., J. L. Nelson, P. C. Ohl, and G. E. C. Bell. 1996. Tank 241-AZ-101 Prototype corrosion probe four-month status report. Rev. 0. WHC-SD-WM-TI-796.

Farrell, D. M. 1991. Industrial Corrosion 9:7.

Hladky, K., and J. L. Dawson. 1982. Corrosion Science 23:231.

Nelson, J. L. 1998. "Responses to questions for GATE review of corrosion probe for Richland and Savannah River Site (Characterization/immobilization/retrieval—Hanford/SRS)."

Ohl, P. C., J. D. Thomson, and F. R. Vollert. 1994 "Corrosion considerations for life management of .Hanford high-level waste tanks," paper no. 142 in proceedings of CORROSION/94. Houston, TX: NACE International. 


\section{LIST OF ACRONYMS}

ASTM American Society for Testing and Materials

DOE Department of Energy

DST double-shell tank

EN electrochemical noise

FTE full-time equivalent

HLW high-level waste

LPR linear polarization resistance

OST Office of Science and Technology

SCC stress corrosion-cracking

SRS Savannah River Site

ZRA zero-resistance ammeter 